\title{
Belgeo
}

Revue belge de géographie

\section{Geomorfologisch, geoarcheologisch, paleoecologisch en paleobotanisch onderzoek van de havenuitbreidingswerken op de linker Scheldeoever ten noorden van Antwerpen}

Geomorphological, geoarcheological, paleoecological and paleobotanical study of the harbour expansion on the left bank of the Scheldt River, north of Antwerp

Lieselotte Meersschaert, Jean-Pierre Van Roeyen et Cyriel Verbruggen

\section{(2) OpenEdition}

Journals

\section{Édition électronique}

URL : http://journals.openedition.org/belgeo/12053

DOI : $10.4000 /$ belgeo.12053

ISSN : 2294-9135

\section{Éditeur :}

National Committee of Geography of Belgium, Société Royale Belge de Géographie

\section{Édition imprimée}

Date de publication : 30 septembre 2006

Pagination : 183-204

ISSN : 1377-2368

\section{Référence électronique}

Lieselotte Meersschaert, Jean-Pierre Van Roeyen en Cyriel Verbruggen, « Geomorfologisch, geoarcheologisch, paleoecologisch en paleobotanisch onderzoek van de havenuitbreidingswerken op de linker Scheldeoever ten noorden van Antwerpen », Belgeo [Online], 3 | 2006, Online op 30 octobre 2013, geraadpleegd op 07 mai 2019. URL : http://journals.openedition.org/belgeo/12053 ; DOI : 10.4000/belgeo.12053

Ce document a été généré automatiquement le 7 mai 2019.

Belgeo est mis à disposition selon les termes de la licence Creative Commons Attribution 4.0 International. 


\section{Geomorfologisch, geoarcheologisch, paleoecologisch en paleobotanisch onderzoek van de} havenuitbreidingswerken op de linker Scheldeoever ten noorden van Antwerpen

Geomorphological, geoarcheological, paleoecological and paleobotanical study of the harbour expansion on the left bank of the Scheldt River, north of Antwerp

Lieselotte Meersschaert, Jean-Pierre Van Roeyen et Cyriel Verbruggen

\section{Inleiding}

Sinds de 70 -er jaren van de $20^{\text {ste }}$ eeuw wordt de haven van Antwerpen ook verder uitgebouwd op de linkeroever van de Schelde, in de zogenaamde Wase Scheldepolders. Deze vaak ingrijpende infrastructuurwerken kregen aanvankelijk weinig aandacht vanuit archeologische hoek. Hierin kwam pas verandering met de aanstelling in 1979 van archeoloog Rudiger van Hove in het kader van het door de gemeente Beveren opgezet historisch-archeologisch onderzoeksproject "Geschiedenis van Volk en Land van Beveren", waarvan het archeologische luik zou worden bestendigd door de oprichting in 1983 van de Archeologische Dienst Waasland (ADW). Vooral dankzij zijn prospecties van de havenuitbreidingswerken en het archeologisch onderzoek van de sites VerrebroekAven Ackers (1981-1983) en Melsele-Hof ten Damme (1984-1986 en 1990) en de samenwerking met fysisch-geograaf en palynoloog Cyriel Verbruggen (Universiteit Gent) ging er meer aandacht naar de Wase Scheldepolders en werd een begin van inzicht verworven in de archeologische en paleolandschappelijke evolutie van het gebied. De realisatie van het Verrebroekdok vormde een nieuwe uitdaging. Van 1992 tot 2000 werd 
voorafgaand aan en tijdens de werken grootschalig archeologisch onderzoek verricht. Hierbij ging de aandacht zowel naar de steentijdsite van Verrebroek-Sint-Michielsstraat (Universiteit Gent, Vakgroep Archeologie en Oude Geschiedenis van Europa, o.l.v. Philippe Crombé), als naar de landschappelijke ontwikkeling en de (post)middeleeuwse bewoning (ADW, o.l.v. Jean-Pierre Van Roeyen). Het waren echter vooral de bouw van het Deurganckdok en de uitvoering van alle eraan verbonden natuurcompensatieprojecten die de definitieve aanzet hebben gegeven tot de geïntegreerde preventieve archeologische en paleolandschappelijke benadering van projectgebieden in de Wase Scheldepolders. Belangrijk in dit kader was de aanwerving door de ADW van eerstgenoemde auteur en Bart Klinck, fysisch-geografen.

In de huidige aanpak ligt de nadruk op preventief onderzoek, nl. het lokaliseren en karteren van archeologische vindplaatsen en het reconstrueren van de landschapsontwikkeling gedurende het Quartair. Op basis van terreinprospectie, hoofdzakelijk aan de hand van boringen (aangevuld met oppervlakteprospectie), wordt getracht een inzicht te krijgen in de geomorfologische structuur en de archeologische potenties van de ondergrond. Hierbij wordt ook veel aandacht besteed aan de methodologische aspecten van het onderzoek.

3 Enerzijds biedt het gebied door zijn ligging in een perimariene randzone en door de soms aanzienlijke dikte van de alluviale pakketten een aantal specifieke en optimale mogelijkheden voor de detectie van zowel zeer oude (paleo-, meso- en neolithische) als jongere (middeleeuwse en postmiddeleeuwse) occupatieniveaus in samenhang met verschillende landschappelijke kenmerken. Anderzijds is de grootschaligheid van de bouwwerken, zowel horizontaal als verticaal, een ideale situatie om zoveel mogelijk gegevens te verzamelen. Er mag dan ook gesteld worden dat deze gegevens reeds een goed beeld, weliswaar nog onvolledig, kunnen schetsen van de evolutie en dynamiek binnen de Wase Scheldepolders.

Wat volgt is een systematisch overzicht van de evolutie op methodologisch vlak en een chronologische synthese van de onderzoeksresultaten.

\section{Situering van het studiegebied en algemene werkwijze}

De Wase Scheldepolders zijn rivierpolders die zich in het noordoosten van de provincie Oost-Vlaanderen bevinden, op de linkeroever van de Schelde. Het gebied wordt in het noorden administratief begrensd door de landsgrens met Nederland, in het oosten door de Schelde en in het zuidwesten door de cuesta van het Land van Waas. Hoewel we ons hier op de lijzijde van de cuesta bevinden, is er meestal een duidelijke grens daar waar de Rupeliaan kleibasis opduikt. In het westen duikt de klei snel naar beneden en worden de alluviale afzettingen begrensd door de Grote Dekzandrug van Maldegem-Stekene.

6 Het is een vlak, alluviaal gebied met een gemiddelde hoogte tussen 2 en $3 \mathrm{~m} \mathrm{TAW}^{1}$;lokaal komen donken met een maximum hoogte tot $5 \mathrm{~m}$ TAW voor. Bodemkundig bestaan deze polders voornamelijk uit zware klei- en kleigronden, maar sporadisch komen meer zandige zones voor (uitlopers van de Grote Dekzandrug).

7 Bij de uitvoering van de havenuitbreidingswerken worden er steeds zeer grote delen van de Scheldepolders aangetast en vernietigd, hetzij door de grootschalige infrastructuurwerken, hetzij door de aanleg van natuurcompensatiezones. In beide gevallen gaat vaak vrijwel alle archeologische en paleoecologische informatie verloren. Er 
kon voor de verschillende projecten een onderzoeksovereenkomst gesloten worden met de Administratie Waterwegen en Zeewezen (AWZ), het Gemeentelijk Havenbedrijf Antwerpen (GHA) en het Intergemeentelijk Samenwerkingsverband van het Land van Waas (I.C.W.) en er kon telkens een deelname in de onderzoekskosten worden bedongen.

Aangezien het steeds om zeer grote oppervlakten gaat, is het onmogelijk om alle zones volledig te onderzoeken. Toch gaat het hier om een zeer interessante regio, omdat op vele plaatsen alle grote fasen in de landschappelijke evolutie van deze regio nog afzonderlijk herkenbaar zijn in de bodem. Zo wordt in de ideale situatie het pleistoceen oppervlak afgedekt door een veenpakket. Tussen het laagste en hoogste topografisch niveau verloopt de aanvang van deze veengroei tussen ca. 6000 en 4000 BP. Dit betekent dat hier een oorspronkelijk postglaciaal oppervlak van voor die tijd werd afgedekt. Het veen zelf bevat een continue paleobotanische en landschappelijke registratie grosso modo tot de $6^{\text {de }}$ en $7^{\text {de }}$ eeuw van onze tijdrekening. Tussen de top van het veen en de sedimenten van de strategische overstromingen uit de late $16^{\text {de }}$ eeuw bevinden zich allerlei sporen en afzettingen uit de tussenliggende middeleeuwen.

Om zo efficiënt mogelijk te kunnen werken, wordt er sinds een aantal jaar geopteerd voor grootschalig, preventief booronderzoek. De bedoeling is dat aan de hand van de bekomen boorgegevens kaarten worden opgesteld die daarna kunnen gebruikt worden om het verdere onderzoek en de begeleiding van de graafwerken zo systematisch en efficiënt mogelijk te laten verlopen. Enerzijds gaat het hierbij om verspreidingskaarten, waarop aangegeven wordt onder welke vorm een bepaalde landschappelijke fase tot uiting komt en anderzijds gaat het om isopachenkaarten die de diepte waarop het fenomeen zich bevindt, weergeven. In de praktijk geven deze kaarten dus aan waar en hoe diep onder het huidige maaiveld men bepaalde landschappelijke en archeologische gegevens kan verzamelen. Het onderzoek en de verwerking van de resultaten gebeurt in verschillende stappen. 
Figuur 1. Lokalisatie van de besproken onderzoekszones binnen de Wase Scheldepolders.

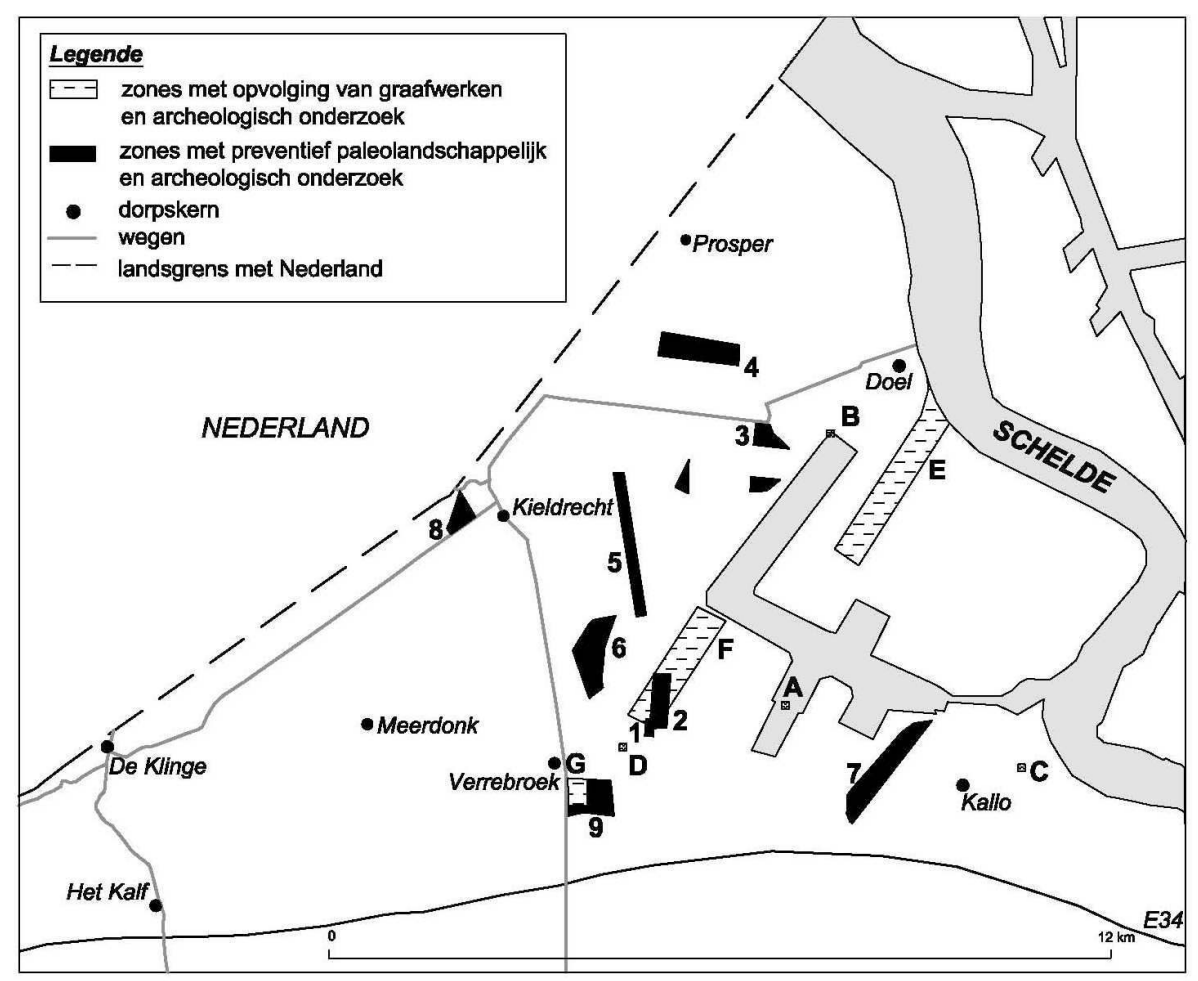

\section{Preventief onderzoek en het opnemen, registreren, coderen en verwerken van alle boorgegevens}

10 Algemeen gezien, zijn in het onderzoek dus twee grote fasen te onderscheiden: de terreinprospectie en het laboratoriumonderzoek. In het verleden werden waarnemingen m.b.t. de landschappelijke ontwikkeling vnl. verricht bij de opvolging van graafwerken, maar sinds een vijftal jaar wordt in de mate van het mogelijke geopteerd voor preventief onderzoek. Dit preventief onderzoek bestaat, naast een archeologisch vooronderzoek o.m. aan de hand van cartografisch onderzoek en oppervlakteprospectie, uit een boorcampagne, waarbij boringen worden uitgevoerd volgens een vast patroon. Er wordt gebruik gemaakt van een Edelmanboor en daar waar de sedimenten veniger worden, wordt de boor gewisseld voor een guts. Op deze manier kan meestal het pleistoceen oppervlak bereikt worden. Paleolandschappelijk gezien, is dit het oudste oppervlak na de laatste ijstijd (met uitzondering van lokale, overdekte laatglaciale zones), wat betekent dat op deze wijze alle mogelijke oppervlakken kunnen gedetecteerd worden.

Om een meer overzichtelijk en gedetailleerd beeld te krijgen van de stratigrafische opbouw van een gebied worden na de preventieve terreinprospectie de graafwerkzaamheden gevolgd. De profielen die beschikbaar komen, laten zien of de reconstructie op grond van de boringen kloppen (validatie). De graafwerken geven ook de mogelijkheid om uitgebreid stalen te verzamelen voor verder onderzoek.

Ook het laboratoriumonderzoek is geëvolueerd. Waar dit oorspronkelijk voornamelijk beperkt bleef tot palynologisch onderzoek, werd dit de laatste jaren uitgebreid met houten houtskoolonderzoek, zaden- en vruchtenanalyse, diatomeeën- en sedimentologisch 
onderzoek. Hierdoor is de kennis over de paleolandschappelijke evolutie van de Wase Scheldepolders sterk toegenomen en verfijnd. Bovendien is het aan de hand van een combinatie van verschillende onderzoekstechnieken mogelijk om een archeologische site te plaatsen binnen een ruimere omgeving. Naast een reconstructie van het lokale en regionale landschap is het bijvoorbeeld ook mogelijk te achterhalen wat lokaal verbouwd werd, wat het consumptiepatroon was, wat de economische betekenis was van de nederzetting, enz.

13 Van elk boorpunt worden op het terrein de geografische coördinaten bepaald aan de hand van een Totaalstation. Nadien worden de eigenlijke boorgegevens gesystematiseerd aan de hand van een codesysteem, waarbij voor iedere boring wordt aangegeven onder welke vorm de laat- en postmiddeleeuwse overstromingssedimenten, het middeleeuws oppervlak, het veen en de pleistocene sedimenten hier voorkomen. Dit is nodig om de verwerking sneller te laten verlopen. In plaats van steeds de volledige beschrijving te moeten lezen, kan men immers op deze manier in één oogopslag zien welke evolutiefasen op die plaats zichtbaar zijn in het bodemprofiel en in welke vorm. Er dient te worden gesteld dat deze codering op een erg pragmatische wijze is ontstaan. Om het stratigrafisch en genetisch begrijpelijker te maken is figuur 2 toegevoegd, waarbij elke voorkomende type-stratigrafie met zijn code is aangegeven. Voor de Wase Scheldepolders wordt volgende codering gebruikt :

Profielen zonder afdekking, m.a.w. wanneer het Pleistoceen aan het oppervlak ligt :

- 1. De humeuze bovenlaag (het actuele oppervlak) is gevormd in de pleistocene afzettingen.

Profielen met afdekking, m.a.w. profielen met overstromingssedimenten en/of veen :

- V. Er is veen aanwezig in het bodemprofiel. (Wegens de belangrijkheid van de aan- of afwezigheid van veen wordt dit symbool steeds vooraan geplaatst.)

16 - 2. Er is geen oorspronkelijk middeleeuws oud oppervlak aanwezig in het bodemprofiel.

Het ontbreken van dit oppervlak kan het gevolg zijn van verschillende situaties. Op sommige plaatsen was het afdekkende kleidek te dun, waardoor het oppervlak samen met het onderliggende dekzand door de agrarische bewerkingen omgevormd werd tot het actuele oppervlak. Op andere plaatsen is het kleidek wel dik genoeg, maar is er toch geen middeleeuws oppervlak te zien, omdat deze vermoedelijk geërodeerd werd tijdens de latere overstromingsfasen.

17 - 3. Er is een middeleeuws oud oppervlak aanwezig in het bodemprofiel.

Op deze plaatsen is het afdekkende kleidek dikker dan de diepte van de huidige agrarische bewerkingen. Bovendien werd het oppervlak niet geërodeerd tijdens (post)middeleeuwse overstromingsfasen. Het resultaat is de aanwezigheid van een donkere, organische, zandige laag bovenop het veen of in de top van het dekzand, indien het pleistoceen oppervlak hoger ligt dan de grens van de veengroei (zie later).

18 - -A. Naast de humeuze bovenlaag (het actuele oppervlak) zijn er nog ongestoorde (post)middeleeuwse overstromingssedimenten van fase 2 aanwezig in het bodemprofiel. In een tweede fase van de (post)middeleeuwse overstromingen werd hoofdzakelijk lichtgrijs zand, kleiig zand of zandige klei afgezet. De nodige gegevens om deze sedimenten verder op te splitsen en te dateren ontbreken voorlopig nog. De hypothese die nu gevolgd wordt, stelt dat deze sedimenten werden afgezet in de periode van de strategische overstromingen (Farnèse) op het einde van de $16^{\text {de }}$, begin $17^{\text {de }}$ eeuw. 
19 - -B. Met uitzondering van de humeuze bovenlaag (het actuele oppervlak) zijn er geen (post)middeleeuwse overstromingssedimenten van fase 2 aanwezig in het bodemprofiel. Op deze plaatsen is het alluviale pakket zeer dun of zelfs afwezig, waardoor er onder de huidige bouwvoor geen overstromingssedimenten kunnen geattesteerd worden. Het gaat hierbij om de hogere delen van het pleistoceen oppervlak, waar ook geen veenpakket voorkomt.

20 - - -zk. Er zijn (post)middeleeuwse overstromingssedimenten van fase 1 aanwezig in het bodemprofiel.

In de oudste fase van de (post)middeleeuwse overstromingen werden zware, donkere kleien afgezet, waarin af en toe een beetje van het onderliggende sediment vermengd zit. Door het ontbreken van archeologische informatie binnen deze afzettingen konden ze nog niet gedateerd worden, maar men vermoedt dat deze sedimenten werden afgezet tijdens de overstromingen in de $13^{\text {de }}, 14^{\text {de }}$ en $15^{\text {de }}$ eeuw.

21 Verstoorde profielen :

- 4. Het bodemprofiel is verstoord.

Sporadisch is de normale stratigrafische opbouw verstoord. Meestal gaat het hierbij om kuilvormige depressies, grachten of geulen die opgevuld werden met allerhande materiaal.

22 Van deze codes worden dan per onderzoeksgebied een aantal typesequenties onderscheiden. Een voorbeeld is de sequentie "V2Azk". Op deze plaats is de humeuze bovenlaag in de (post)middeleeuwse overstromingssedimenten gevormd, zijn er overstromingssedimenten uit zowel fase 1 als fase 2 aanwezig, is er geen middeleeuws oud oppervlak zichtbaar en zit er een veenlaag bovenop de pleistocene afzettingen.

Deze gegevens worden daarna geïnformatiseerd en ingebracht in een databank en een GIS-programma. 
Figuur 2. Schematisch voorstelling van de gebruikte codering.

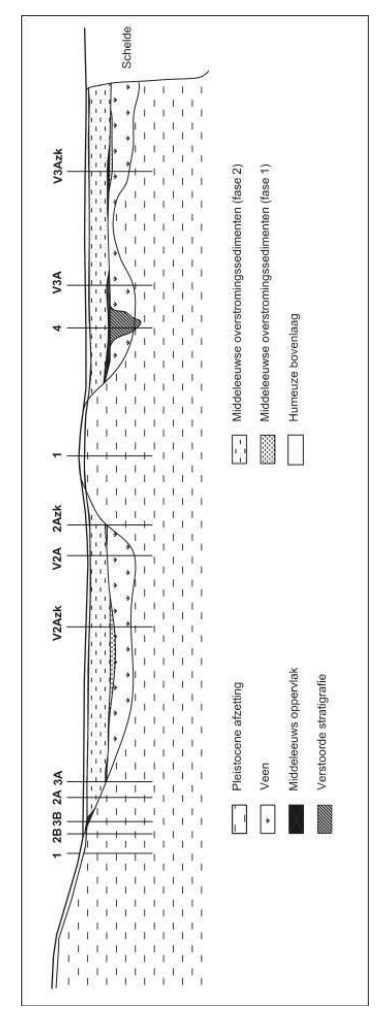

\section{Occupatiefasen "Plas Drijdyck"}

Voor de verschillende onderzoekszones binnen de Wase Scheldepolders konden tot nu toe aan de hand van de boorresultaten kaarten van drie verschillende evolutiefasen opgemaakt worden : de vorming van een zgn. "pre-veen" oppervlak, de veenvorming en de middeleeuwse occupatie. De wijze waarop de kaarten tot stand komen, wordt verduidelijkt aan de hand van een voorbeeld, nl. de onderzoekszone "Plas Drijdyck".

\section{Het "pre-veen" oppervlak}

Voor het opstellen van de verspreidingskaart van het "pre-veen" oppervlak wordt er steeds vertrokken van de vraag waar er nog ongestoorde sporen en/of artefacten uit de Steentijd kunnen teruggevonden worden. In de praktijk komt dit in de eerste plaats neer op de zones die tijdens het Atlanticum en/of Subboreaal bedekt werden met een laag veen. Deze plaatsen worden op de kaart aangeduid als zones met een pleistoceen "preveen" oppervlak. Op de plaatsen waar er geen veen (meer) voorkomt bovenop het pleistoceen dekzand, maar waar wel middeleeuwse overstromingssedimenten werden afgezet, bestaat de kans dat er toch nog (vooral diepere) sporen in situ uit de Steentijd kunnen worden teruggevonden. Het is echter ook mogelijk dat alles "weggespoeld" werd als gevolg van de laat- en postmiddeleeuwse overstromingen. Deze plaatsen worden op de kaart aangeduid als zones met een geërodeerd pleistoceen "pre-veen" oppervlak. De hogere plaatsen van het pleistoceen oppervlak zijn nooit bedekt met veen. Er werd geen of maar een dunne laag afgezet. Hierdoor werd het dekzandoppervlak herwerkt in de middeleeuwse en/of huidige bouwvoor. Het gevolg is dat er misschien wel nog artefacten 
uit de Steentijd kunnen gerecupereerd worden, maar niet meer in hun oorspronkelijke situatie. Deze plaatsen worden op de kaart omschreven als zones zonder "pre-veen" oppervlak (herwerkt in middeleeuws oppervlak of in huidige bouwvoor). Ze hebben voor het archeologisch onderzoek minder waarde en kunnen aan de hand van oppervlakteprospecties onderzocht worden.

Naast de aanduiding van de prioritaire zones in het kader van de steentijdarcheologie, wordt er voor de zones met een pleistoceen "pre-veen" oppervlak ook berekend op welke diepte dit oppervlak zich bevindt. Deze waarden worden weergegeven op een isopachenkaart, waarbij er gewerkt wordt met een interval van $20 \mathrm{~cm}$.

Figuur 3. Verspreidingskaart van de zones met een "pre-veen" oppervlak : Plas Drijdyck (Van Roeyen (red) 2004b).

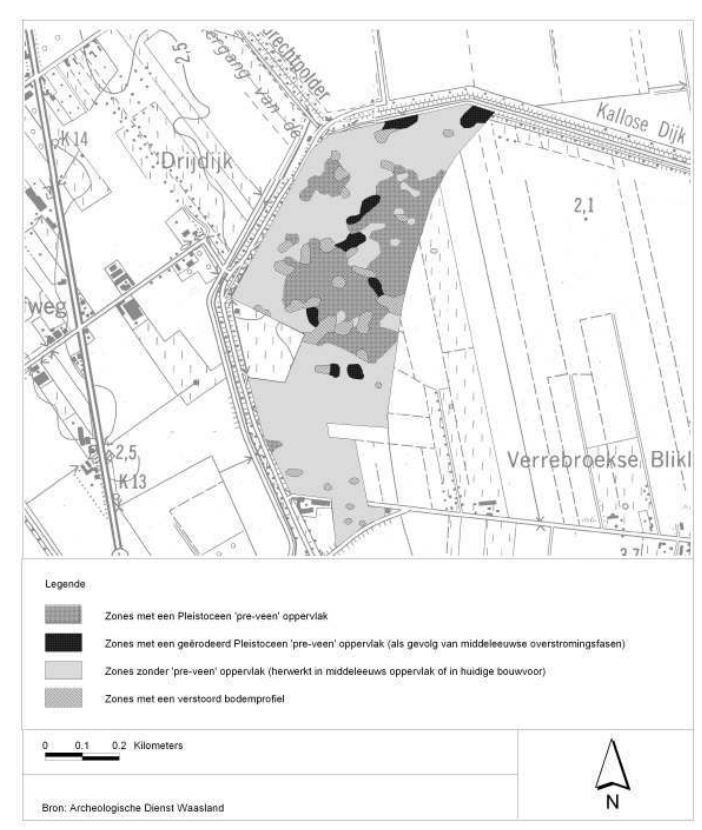


Figuur 4. Isopachenkaart van de afdekking van het pleistoceen "pre-veen" oppervlak : Plas Drijdyck (Van Roeyen (red) 2004b).

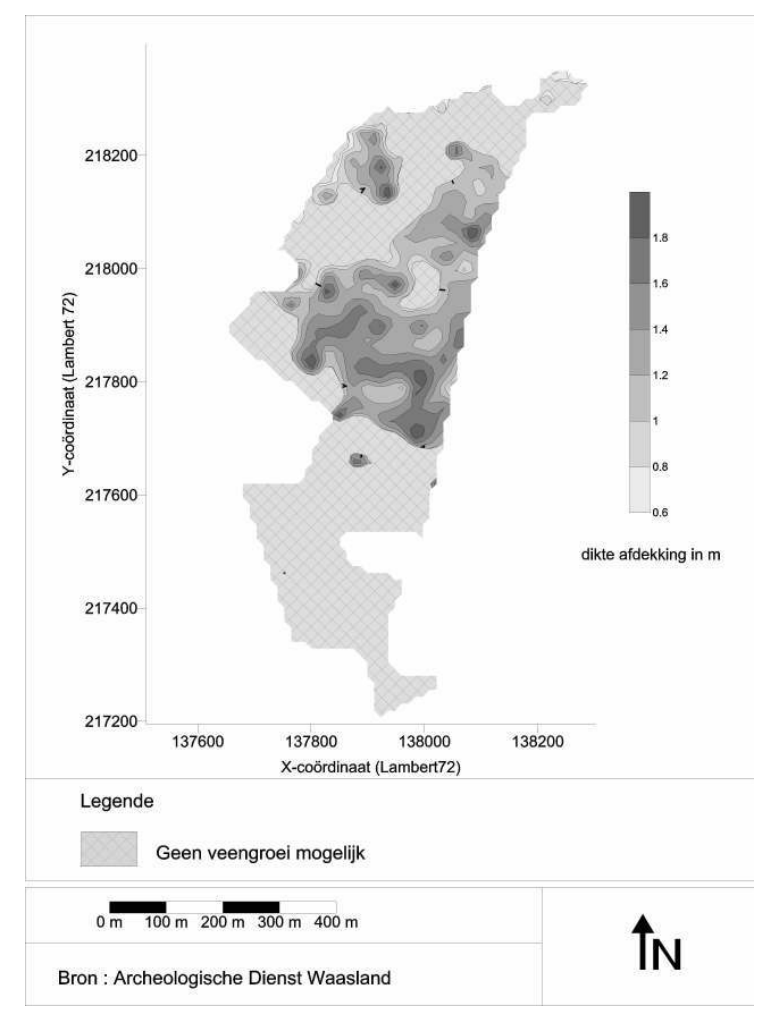

\section{De veenvorming}

Zoals hierboven reeds werd vermeld, wordt de verspreidingskaart van het "pre-veen" oppervlak voor een groot deel opgemaakt op basis van de aan- of afwezigheid van veen bovenop het pleistoceen dekzand. Uit voorgaand onderzoek is echter gebleken dat de huidige toestand van het veenoppervlak in de Scheldepolders niet altijd overeenstemt met de oorspronkelijke situatie. Aan de hand van terrein- en literatuuronderzoek is immers gebleken dat op vele plaatsen minstens een deel van het veen ontgonnen is tijdens de late- en postmiddeleeuwen. Aangezien men hier dikwijls op de randzone van het veengebied zit, is het echter niet altijd mogelijk om via boringen te zien of het veen in situ zit of niet en/of er al dan niet werd uitgeveend. Om te achterhalen wat de oorspronkelijke situatie was, werd daarom getracht om een theoretische grens te bepalen tot op welke hoogte op het dekzandoppervlak veengroei nog mogelijk is geweest. De snelheid waarmee het zeespiegelpeil gedurende het Holoceen steeg, nam vanaf een bepaald moment immers sterk af, waardoor de uitbreiding van het veen tot stilstand kwam. Voor het gebied van de Beneden-Schelde ligt deze grens tussen 1 en $2 \mathrm{~m}$ TAW. Deze grens moet echter per gebied nauwkeuriger vastgelegd worden, omdat de waarde afhankelijk is van de lokale topografie van het pleistoceen oppervlak, de afstand tot de toenmalige Schelde, enz.

De grenswaarde wordt bepaald aan de hand van het verwerken en vergelijken van de boorgegevens door het opmaken van dwarsprofielen en kaarten. De dwarsprofielen tonen het continu verloop van het pleistoceen oppervlak en de veenlaag over een grote afstand, waarbij onregelmatigheden tot uiting komen en het dus mogelijk is om de grens bij 
benadering te bepalen. Daarna worden er kaarten gemaakt waarbij er verschillende grenswaarden "getest" worden. In grote lijnen gebeurt dit als volgt : eerst wordt voor elk boorpunt bepaald wat de hoogte is van het pleistoceen oppervlak, waarbij deze waarde wordt geconfronteerd met de theoretisch vooropgestelde grenswaarde. Er wordt dan vastgesteld of er veen aanwezig zou moeten zijn of niet. In een tweede stap wordt de uitkomst van deze confrontatie vergeleken met de werkelijke situatie. Om een algemeen beeld te krijgen van de uitkomst, wordt daarna een kaart gemaakt voor het hele studiegebied, waarbij er aangeduid wordt, welke plaatsen beantwoorden aan de theorie en welke niet. Als er te veel verschillen zijn tussen de theoretische en de werkelijke situatie, wordt de grens met $5 \mathrm{~cm}$ verlegd, waarna de waarden opnieuw worden getoetst aan de nieuwe theoretische grens. Op deze manier wordt dan uiteindelijk de "best passende" waarde geselecteerd en de theoretische grenswaarde voor deze zone vastgelegd. Voor het gebied Plas Drijdyck werd deze grens vastgelegd op 1.25 m TAW, m.a.w. waar het pleistoceen oppervlak hoger ligt dan $1.25 \mathrm{~m} \mathrm{TAW}$, is er hier theoretisch gezien geen veen meer beginnen groeien.

$\mathrm{Na}$ het vastleggen van de grenswaarde, wordt er een verspreidingskaart van het veenoppervlak opgesteld waarop de zones afgebakend worden waar het veen vermoedelijk ongestoord aanwezig is (waarbij de werkelijke situatie dus in overeenstemming is met de theoretische), waar er mogelijk veen verdwenen is (als het pleistoceen oppervlak beneden de grenswaarde ligt, maar er geen veen aanwezig is) of waar er veen gedeponeerd werd (als het pleistoceen oppervlak boven de grenswaarde ligt, maar er toch veen werd gevonden).

Naast de verspreidingskaart wordt er opnieuw een isopachenkaart opgemaakt, om weer te geven op welke diepte het veen kan worden aangetroffen.

\section{De middeleeuwse occupatie}

Bij de opgravingen in het Verrebroekdok is duidelijk gebleken dat er op het uitgeveend oppervlak een nieuw oppervlak is gecreëerd dat blijkt te bestaan uit een menglaag van zand en veenrestanten. Ook in Plas Drijdyck en in Verrebroek-Aven Ackers is deze laag meerdere malen aangetroffen. De grote verspreiding van deze laag, die wordt omschreven als middeleeuws oppervlak, levert goede perspectieven voor de juiste bepaling van de oorsprong en de mogelijke ouderdom ervan. Dit kan op zich dan weer meer duidelijkheid verschaffen in de discussie tussen historici, archeologen, paleobotanisten, pedologen en geomorfologen over de oorspronkelijke verbreiding van het veen en de aard en intensiteit van de ontginning ervan. Bovendien is uit voorgaand onderzoek gebleken dat er aanzienlijke (post-)middeleeuwse menselijke activiteit is geweest in de Wase Scheldepolders, waardoor deze streek op dit vlak een grote archeologische potentie heeft.

Door het groot belang van het middeleeuws oppervlak besloot men om ook van dit aspect een verspreidings- en isopachenkaart op te stellen. Op de verspreidingskaart wordt weergegeven waar de prioritaire zones zich bevinden. Algemeen gezien zijn dit de zones waar het middeleeuws oppervlak niet verstoord werd door latere bewerkingsfasen, m.a.w zijn het de zones waar een dik pakket alluviale afzettingen aanwezig is. Binnen deze klasse wordt er een onderscheid gemaakt tussen de zones waar er een duidelijk te onderscheiden laag bovenop het veen aanwezig is (zone met een herkenbaar middeleeuws oppervlak) en de zones waar deze laag niet (meer) aanwezig is (zone met 
een onherkenbaar middeleeuws oppervlak). Op de plaatsen die behoren tot deze laatste categorie kan wel nog het potentiële loopvlak uit die periode gereconstrueerd worden, maar de bewerkingslaag is hier vermoedelijk geërodeerd tijdens de latere overstromingsfase(n). De zones met een dun pakket of zelfs zonder overstromingssedimenten zijn minder interessant, omdat de middeleeuwse sporen gedeeltelijk of volledig werden opgenomen in de huidige bouwvoor. Er kunnen dan wel nog middeleeuwse artefacten gevonden worden, maar waarschijnlijk niet meer in hun oorspronkelijke toestand. De diepere sporen, zoals grachten of kuilen, kunnen wel nog gelokaliseerd worden, maar dit kan dan eveneens gebeuren aan de hand van oppervlakteprospectie.

Opnieuw wordt ook een isopachenkaart opgesteld om aan te duiden op welke diepte onder het huidige maaiveld het middeleeuws oppervlak zich bevindt.

Het preventief onderzoek en het daaruit voortvloeiende kaartenmateriaal zorgt er dus in grote lijnen voor dat het eigenlijke archeologisch en paleolandschappelijk onderzoek zo efficiënt en systematisch mogelijk kan verlopen. Er wordt immers heel wat tijd, werk en geld gespaard door zich voornamelijk op de meest interessante zones te kunnen concentreren, zonder het risico te lopen belangrijke plaatsen en zaken over het hoofd te zien.

Figuur 5. Verspreidingskaart van de zones met veen : Plas Drijdyck (Van Roeyen (red) 2004b).

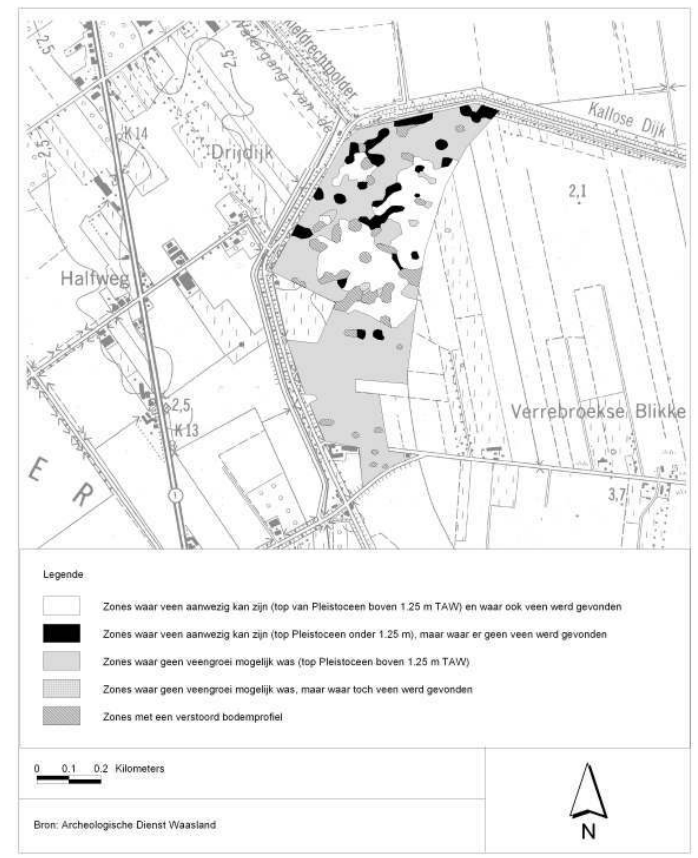


Figuur 6. Verspreidingskaart van het middeleeuws oppervlak : Plas Drijdyck (Van Roeyen (red) 2004b).

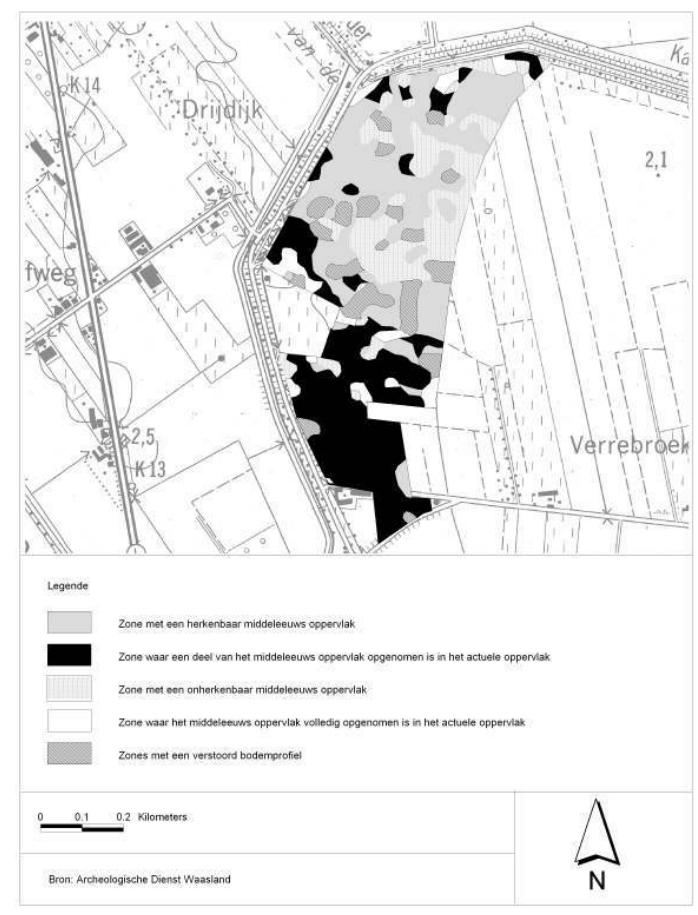

\section{De landschappelijke ontwikkeling van de Wase Scheldepolders}

Wat volgt is een diachronische synthese van de landschappelijke ontwikkeling van de Wase Scheldepolders op basis van de tot nu toe verzamelde gegevens.

Dit overzicht zal hoofdzakelijk beperkt worden tot het Quartair, maar aangezien er in Deurganckdok en Verrebroekdok ook gegevens konden verzameld worden over de pliocene sedimenten (laatste periode van het Tertiair), worden deze voor de volledigheid ook meegegeven.

\section{Plioceen (5.3 - $1.8 \mathrm{Ma})$}

Uit het onderzoek van dinoflagellaten en palynomorfen in Deurganckdok en Verrebroekdok (Louwye et al 2004) blijkt dat de pliocene sedimenten werden afgezet in een shelf-milieu in een gematigd tot koud klimaat. Naar analogie met vroeger onderzoek in de Antwerpse haven (rechteroever), konden twee formaties onderscheiden worden : de Kattendijk- en de Lilloformatie. De Kattendijksedimenten werden afgezet in thermofiele, bijna oceanische omstandigheden tussen 5.0 en 4.4 Ma. Na een hiaat van ongeveer 0.2 Ma, werd gedurende één grote afzettingsperiode de Lilloformatie afgezet. Deze formatie kan opgesplitst worden in de "Basal Shelly Unit", de "Oorderen-zanden" en de "Kruisschanszanden". De Basal Shelly Unit en de basis van de Oorderen-zanden werden afgezet in relatief koude, transgressieve omstandigheden; het bovenste deel van de Oorderen- 
zanden en de Kruisschanszanden werden afgezet in warmer, ondiep water. De afzetting van de Lillo-formatie werd beëindigd voor $2.6 \mathrm{Ma}$.

\section{Quartair (1.8 Ma - heden)}

\section{Pleistoceen} gedeelte van noordelijk Vlaanderen (ter hoogte van de Vlaamse vallei), het Tertiair substraat in de Wase Scheldepolders ondiep voorkomt. De pliocene sedimenten dagzomen zelfs ter hoogte van Kieldrecht (Van Roeyen (red) 2004a). Hieruit mag worden geconcludeerd dat in deze zone het oppervlak zich steeds in een erosieve situatie bevond, tenminste tot in het vroege Weichsel.

\section{Weichsel}

De oudste pleistocene sedimenten die worden aangetroffen, behoren dus tot het Weichsel. In het Onder-Pleni-Weichseliaan (65.000-25.000 BP) werd veel erosiemateriaal van de Wase cuesta geaccumuleerd in zandige banken en afgesloten kommen. Samen met de löss die vanuit het noorden aanwaaide, en het organisch materiaal van de toendravegetatie ontstonden hieruit de zogenaamde peaty loam-formaties, welke binnen het onderzoeksgebied tot nu toe uitsluitend en enkel sporadisch in het Deurganckdok werden teruggevonden (Van Roeyen et al 2001).

In het Boven-Pleni-Weichseliaan (25.000-13.000 BP) werden de afgezette sedimenten eolisch herwerkt, wat resulteerde in een reliëfrijk landschap, waarin ruggen en kommen elkaar afwisselden.

41

Een volledig gedetailleerd beeld van de topografie van het pleistocene oppervlak binnen het onderzoeksgebied is nog niet voorhanden, omdat er nog te weinig onderzochte zones opgemeten werden, zodat maar voor een aantal onderzoekszones exacte TAW-waarden bekend zijn. Uit de verzamelde gegevens kan wel opgemaakt worden dat de Grote Dekzandrug Maldegem-Stekene in het oosten grofweg kan begrensd worden ter hoogte van de dorpen Kieldrecht en Verrebroek, met hier en daar enkele uitlopers in meer oostelijke richting. Meer naar de Schelde toe zakt de top van het dekzand. Tijdens reeds uitgevoerde prospecties binnen het onderzoeksgebied kon vastgesteld worden dat dit verloop niet rechtlijnig is en dat er hier en daar relatief kleinschalige, maar toch duidelijke opduikingen aanwezig zijn. Zo kan bijvoorbeeld de onderzoekszone Plas Drijdyck opgesplitst worden in twee verschillende zones : in het zuidelijk deel bevindt de top van de pleistocene dekzanden zich op een hoogte van ongeveer $+3 \mathrm{~m}$ TAW, terwijl die meer noordelijk daalt tot ongeveer $+0.5 \mathrm{~m}$. In het zuidelijk deel van de zone ter hoogte van de geplande Zoetwaterkreek (aansluitend bij het noordelijk deel van Plas Drijdyck) stijgt de top weer tot $+1.5 \mathrm{~m}$, om daarna definitief te zakken en nu tot een diepte van ongeveer $-1.5 \mathrm{~m}$ TAW. 
Figuur 7. Algemene stratigrafie van het Deurganckdok als voorbeeld voor de Wase Scheldepolders.

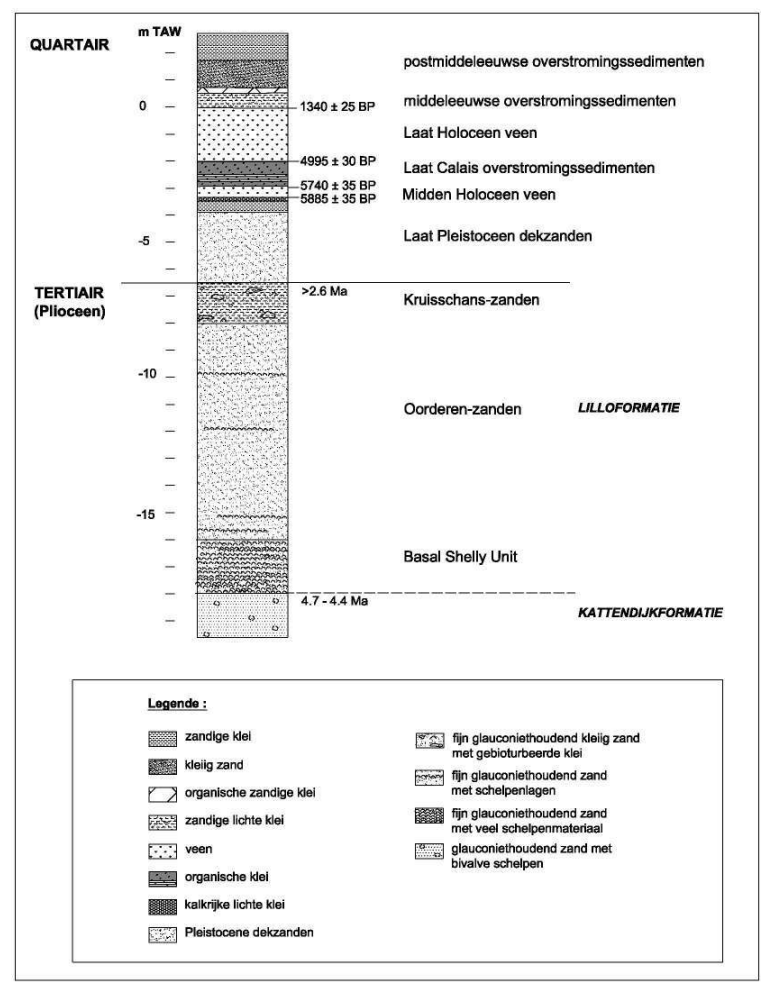

\section{Laatglaciaal}

Naar analogie met verschillende andere plaatsen op en ter hoogte van de zuidelijke helling van de Grote Dekzandrug Maldegem-Stekene (Vanhoorne \& Verbruggen 1975, Verbruggen 1979), werden er ook in de Wase Scheldepolders organische afzettingen uit het Laatglaciaal (13.000-10.300 BP) teruggevonden. Zo waren bij de werken aan het Verrebroekdok een aantal plasstructuren en veenbandjes erg duidelijk te zien in de nabijheid van de mesolithische site van Verrebroek-Sint-Michielsstraat (Crombé (ed.) 2005). In overeenstemming met de rest van Vlaanderen bleek het op basis van de vegetatiesamenstelling en de dateringen ook hier zeer moeilijk te zijn om de organische bandjes te plaatsen binnen de Bølling- of Allerød-periode. Na uitgebreid onderzoek is men er toch in geslaagd om tot een consensus te komen. De diepste venige band werd aan de hand van 14C-onderzoek gedateerd op $11.900 \pm 90$ BP (Utc-9434), wat overeenstemt met de Bølling-periode. Deze datering werd tevens bevestigd door het palynologisch onderzoek. Bovendien bleek uit dit onderzoek dat de laag was afgezet in een bijna boomloze omgeving, meer bepaald in een zegge-moeras (Crombé (ed) 2005). De bovenliggende, duidelijk afgescheiden veenbandjes werden gedateerd tussen $11.760 \pm 60$ (NZA-11018) en $10.710 \pm 75$ BP (NZA-11520), welke binnen de Allerød-periode vallen (Van Roeyen (red) 2003b). De pollen uit dit pakket wijzen op een opeenvolging van verschillende fasen, waarbij de vegetatie afwisselend meer open en gesloten was. Voor het totale pakket kan men concluderen dat het werd afgezet in een ondiep moeras (Crombé (ed) 2005). 

voor deze periode Pinus sp. (den) en Corylus avellana (hazelaar) de meest geattesteerde soorten waren en dat het belang van Quercus sp. (eik) in deze periode gradueel steeg. Dit vegetatief beeld is volledig in overeenstemming met de rest van Zandig Vlaanderen (Verbruggen et al 1996). De mesolithische haardkuilen in Deurganckdok bleken iets jonger te zijn; ze werden hoofdzakelijk gedateerd tussen $7865 \pm 35$ BP en $7580 \pm 35$ BP. De resultaten uit het onderzoek van deze contexten tonen een dominantie van Quercus sp. naast Alnus sp. (els), Tilia sp. (wilg), Corylus avellana en Ulmus sp. (olm). 
Uit de aanwezigheid van een sterk organische laag bovenop het niveau met de haardkuilen blijkt dat er in de periode na het Mesolithicum nog mensen hebben verbleven op de hoogste delen van het dekzandlandschap. Deze laag werd uitvoerig onderzocht en geplaatst in het Vroeg-Neolithicum, meer bepaald in de Swifterbantperiode. Aan de hand van de studie van een nabijgelegen veensequentie (Gelorini et al. in press) weet men dat in die periode reeds veen was beginnen groeien in de lagere delen van het landschap en dat de veengroei bovendien op sommige plaatsen werd onderbroken door een overstromingsfase, de zogenaamde Calais-overstromingen. In de afvallaag werden talrijke visresten aangetroffen. Men mag stellen dat bij deze Calais-overstromingen voor het eerst een omvangrijk water- en moerasgebied is ontstaan in de Beneden-Schelde, wat ongetwijfeld een invloed zal uitgeoefend hebben op de leefen voedselgewoonten van de toenmalige bevolking.

De resultaten van het paleobotanisch onderzoek van de Swifterbantlaag bovenop de "donk" duiden op de aanwezigheid van wat vandaag een hardhoutooibos wordt genoemd. Dit soort bos is typisch voor de rand of de hogere delen van een alluviale vlakte die hoogstens enkele keren per jaar overstromen. Het bovenste bladerdek bestaat in dit bos uit Fraxinus excelsior (es), Ulmus sp. en Quercus sp. en de struiklaag wordt opgebouwd uit Prunus spinosa (sleedoorn), Corylus avellana, Cornus sanguinea (rode kornoelje), Crataegus monogyna (eenstijlige meidoorn) en Viburnum opulus (Gelderse roos).

$\mathrm{Na}$ het beëindigen van de Calais-overstromingen rond 5000 BP begon er terug veen te groeien in de overstromingszones en tijdens deze fase werden nu ook de hogere delen van het pleistoceen landschap bedekt als gevolg van een nog steeds stijgende zeespiegel. Dit betekende dan ook meteen het einde van een lange occupatieperiode, waarbij de mens definitief de nu nog bestaande pleistocene hogere delen moest gaan opzoeken. Een uitgebreide beschrijving van het veenlandschap gebeurt in het artikel "Paleobotanisch onderzoek van een Holocene veensequentie uit het Deurganckdok te Doel (Wase Scheldepolders, Noord-België)" (Gelorini et al., in press).

\section{Het (post) middeleeuwse landschap}

\section{De (post)middeleeuwse overstromingen}

52 Het middeleeuwse veenlandschap veranderde in de $13^{\mathrm{de}}$ en $14^{\text {de }}$ eeuw aanzienlijk toen men in de Wase Scheldepolders begon met het ontginnen van veen, waardoor er een verlaagd, nieuw oppervlak tot stand kwam en waarbij er ontwateringsriolen door het hele gebied werden aangelegd. Bovendien veranderde de getijdenamplitude doordat de Westerschelde functioneel werd en door opstuwing als gevolg van de bouw van dijken. Het aanzienlijk verlaagde gebied was hierdoor veel kwetsbaarder geworden. Voor het eerst treedt een nieuw overstromingssysteem in werking, namelijk de fatale rampoverstromingen ten gevolge van dijkbreuken in een kunstmatig beschermd gebied.

Algemeen gezien kan men voor de Wase Scheldepolders stellen dat het onderste en grootste deel van het overstromingspakket op een energierijk afzettingsmilieu en het bovenste, kleiig pakket eerder op een kalmer afzettingsmilieu wijst. Sporadisch zit er echter onder het pakket dat zojuist werd beschreven nog een laagje sterk organische, zandige klei.

54 De datering van de overstromingssedimenten is voorlopig nog vaag. Doordat deze sedimenten verplaatst materiaal bevatten, is dit immers op een rechtstreekse manier 
onmogelijk. In Deurganckdok werd er wel een $12^{\text {de }}-13^{\text {de }}$-eeuwse greppelstructuur gevonden die ingegraven was vanaf de veentop. In een nabijgelegen zone werd er bovendien een middeleeuwse site gevonden die aanvankelijk op basis van de aangetroffen archeologica globaal werd gedateerd tussen 1375 en 1425, maar wellicht dient geplaatst te worden tussen 1407 en 1424. Deze bevond zich in het pakket overstromingssedimenten, ongeveer $80 \mathrm{~cm}$ boven de veentop. Op basis van deze bevindingen kan men afleiden dat het tussenliggende pakket is afgezet in de tussenliggende periode.

Voorlopig wordt aangenomen dat het onderste organisch-kleiige laagje werd afgezet tijdens de eerste overstromingsfasen van de $13^{\mathrm{de}}, 14^{\mathrm{de}}$ en $15^{\mathrm{de}}$ eeuw. De meest bekende overstromingen voor deze periode zijn de Sint-Clemensvloed (1334) en de StElisabethsvloeden $(1404,1421,1424)$. De rest van het pakket werd vermoedelijk afgezet tijdens de strategische overstromingen op het einde van de $16 \mathrm{de}$ en begin van de $17^{\text {de }}$ eeuw, de zogenaamde Farnèse-overstromingen (1584-1622).

\section{Het (post)middeleeuwse polderlandschap}

Bij de graafwerken voor de kaaimuren van het Deurganckdok konden de overstromingssedimenten gedetailleerd onderzocht worden. Zo werd er in de top van het veen een greppelsysteem teruggevonden (zie hoger). In een latere fase werden deze greppelstructuren oversneden door rijen ingeheide takken die waarschijnlijk behoren bij dijkconstructies. Het zaden- en vruchtenonderzoek van de vulling van een aantal greppels duidt in de richting van een landschap dat gedomineerd werd door weidegronden. Bovendien bleek uit dit onderzoek dat er waarschijnlijk op het einde van de 12 de en in de $13^{\text {de }}$ eeuw nog geen bewoning aanwezig was in dit gebied en er niet of nauwelijks aan akkerbouw werd gedaan (Van Roeyen (red) 2003a) .

Ten noorden van deze zone werden duidelijke bewoningssporen gevonden die gedateerd werden in de vroege $15^{\text {de }}$ eeuw (1407-1424). Ze bevonden zich in de top van een organisch, kleiig pakket, op ca. $60-80 \mathrm{~cm}$ boven de veentop. Het ging hierbij om grachten die heel wat archeologica en organisch materiaal bevatten. Ook hierop werd een uitgebreid zadenen vruchtenonderzoek uitgevoerd (Van Roeyen (red) 2003a). Naast de wilde planten die meestal voorkomen op en rond een nederzetting, werden heel wat cultuurplanten ontdekt. Het ging hierbij om verschillende graangewassen (Triticum sp. (tarwe) en Secale cereale (rogge)), fruit- en notensoorten (Corylus avellana (hazelnoten), Juglans regia (walnoten), Malus sylvestris (appels), Mespilus germanica (mispels), Ficus carica (vijgen), Vitis vinifera (druiven), Prunus domestica (pruimen), Prunus avium (kersen), Rubus fruticosus (bramen) en Rubus idaeus (frambozen)) en tuin- en/of gebruiksplanten (Dipsacus sativus (weverskaarde), Onopordum acanthium (wegdistel), Euphorbia lathyris (kruisbladige wolfsmelk), Humulus lupulus (hop), Linum usitatissimum (vlas) en Reseda luteola (wouw)). Welke gewassen ter plaatse geteeld werden en welke gewassen er werden aangevoerd uit andere gebieden, is aan de hand van het zaden- en vruchtenonderzoek niet uit te maken. Er wordt wel vermoed dat een groot deel van voornoemde soorten werden aangevoerd, hetzij uit de nabije omgeving, hetzij uit verder gelegen gebieden. In de nabije toekomst moet de pollenanalyse hierover meer duidelijkheid verschaffen.

58 Bij de aanleg van het meer zuidelijk gelegen Verrebroekdok werd er eveneens (post)middeleeuwse aanwezigheid vastgesteld, meer bepaald uit de periode einde $14^{\text {de }}$ eeuw-einde $16^{\text {de }}$ eeuw (Gelorini et al., 1999/2000). De onderzoekszone gaf de mogelijkheid om een vergelijking te maken tussen het landschap van de hoger gelegen woestines en dat 
van de lager gelegen veengronden. Het vegetatiebeeld van de zuidelijk, hoger gelegen zandgronden toont voor deze periode een sterk agrarisch open landschap met niet al te omvangrijke bossen en struwelen. De meer noordelijke veengronden die af en toe bedekt waren met een dunne laag alluvium werden gekenmerkt door een afwisseling van heide, weiden en in mindere mate bossen en struwelen. Bovendien was in deze periode de veenontginning nog een belangrijke activiteit in de polders, meer specifiek in de Haendorppolder.

Het onderzoek van de cultuurgewassen heeft voor deze zone interessante informatie geleverd in verband met de ter plaatse geteelde gewassen. Dit was mogelijk omdat naast het zaden- en vruchtenonderzoek er ook een pollenanalyse werd uitgevoerd. Indien er van een soort zowel zaden als pollen aanwezig zijn, is de kans immers zeer groot dat het hier om lokale vegetatie gaat. Zo werd duidelijk dat op het einde van de $14^{\text {de }}$ eeuw voornamelijk granen werden geteeld op de zandgronden. Op het einde van de $15^{\mathrm{de}}$ eeuw, de periode waar er voor het eerst effectief bewoning werd vastgesteld, verschijnen daarnaast ook enkele groentesoorten, keukenkruiden en peulvruchten (Beta vulgaris (bieten), Vicia faba (tuinbonen) en waarschijnlijk ook Allium sp. (look), Thymus sp. (tijm) en Anethum graveolens (dille)). Daarnaast werd er ook reeds Linum usitatissimum en Humulus lupulus geteeld en waren er ook tuin- en sierplanten aanwezig (bijv. Euphorbia lathyris). In de $16^{\mathrm{de}}$ eeuw wordt de verzameling van geattesteerde cultuurplanten nog uitgebreid met Foeniculum vulgare (venkel) en Buxus sempervirens (buxus).

Bij de strategische overstromingen op het einde van de $16^{\text {de }}$ en het begin van de $17^{\text {de }}$ eeuw gingen de oude Scheldepolders onherroepelijk verloren en werd het min of meer uniforme kleidek afgezet dat de huidige Scheldepolders typeert. Voor bepaalde zones betekende dit tevens de eerste aanvoer van sediment boven op het veen of de in cultuur gebrachte zandgronden. Bij de herindijking (vnl. gedurende de $17^{\mathrm{de}}$ en $18^{\mathrm{de}} \mathrm{s}$ ) ontstonden een nieuw landschap, een nieuw dijkenpatroon en een nieuwe ordening van de bewoning.

\section{BIBLIOGRAPHIE}

BATS M. (2001), Prospectie- en waarderingsonderzoek van twee steentijdsites in Zandig Vlaanderen, Onuitgegeven licentiaatsverhandeling, Universiteit Gent.

CROMBÉ Ph. (red) (2005), The last hunter-gatherer-fishermen in Sandy Flanders (NW-Belgium), The Verrebroek and Doel Excavation Projects, Volume 1: Palaeo-environment, chronology and features, Archaeological Reports Ghent University 3.

GELORINI V., MEERSSCHAERT, L. \& VAN ROEYEN JP. (1999/2000), “Archeobotanisch onderzoek van enkele laat- en postmiddeleeuwse archeologische contexten uit de onderzoekszone Verrebroekdok (Beveren, prov. Oost-Vlaanderen)", Archeologie in Vlaanderen, VII, pp. 201-224.

GELORINI V., MEERSSCHAERT L., VERLEYEN E. \& VERBRUGGEN C., in press, Paleobotanisch onderzoek van een Holocene veensequentie uit het Deurganckdok te Doel (Wase Scheldepolders, NoordBelgië). 
JANSSENS W. en FERGUSON D.K. (1985), “The palaeoecology of the Holocene sediments at Kallo, Northern Belgium", Review of Palaeobotany and Palynology, 46, pp. 81-95.

JOOS S. (1985), Onderzoek naar de uitvening in de Wase Scheldepolders, op basis van pollenanalyse, Onuitgegeven licentiaatsverhandeling, Universiteit Gent.

LOUWYE S., HEAD M.J. en DE SCHEPPER S. (2004), "Dinoflagellate cyst stratigraphy and palaeoecology of the Pliocene in northern Belgium, southern North Sea Basin”, Geol. Mag., 141, pp. 353-378.

MINNAERT G. en VERBRUGGEN C. (1986), "Palynologisch onderzoek van een veenprofiel uit het Doeldok te Doel", Bijdragen van de Archeologische Dienst Waasland I, Buitengewone uitgaven van de Koninklijke Oudheidkundige Kring van het Land van Waas, deel 19, pp. 201-208.

MINNAERT G. en VERBRUGGEN C. (1991), Palynologisch onderzoek : Hof ten Damme, Intern rapport, Laboratorium van Regionale geografie en Landschapskunde, Universiteit Gent.

SMITZ I. (1998), Reconstructie van het fysisch-geografisch landschap rond de mesolithische site van Verrebroek (Oost-Vlaanderen), Onuitgegeven licentiaatsverhandeling, Universiteit Gent.

VAN DE WIELE S. (2000), Bijdrage tot de kennis van de landschapsgeschiedenis van de Wase polders voor de Farnèse-overstromingen, Onuitgegeven licentiaatsverhandeling, Universiteit Gent.

VANHOORNE R. \& VERBRUGGEN C. (1975), "Problèmes de subdivision du Tardiglaciaire dans la région sablonneuse du Nord de la Flandre en Belgique", Pollen et spores, XVII, 4, pp. 525-543.

VAN HOVE R. \& VAN ROEYEN J.P. (1996), Jaarverslag 1996 : Verrebroek-Bufferzone, Archeologische Dienst Waasland, pp. 1-31.

VAN ROEYEN J.-P. (1990), Mesolithische bewoning in de Wase Scheldepolders - opgravingen en prospecties (1981-1983), Onuitgegeven licentiaatsverhandeling, Universiteit Gent.

VAN ROEYEN J.-P. (red) (2001), Paleolandschappelijk, paleo-ecologisch en archeologisch onderzoek van de op te hogen gronden in het kader van MIDA 1 en MIDA 2 en van de graafwerken voor de kaaimuren van het Containergetijdendok-West (Gemeente Beveren), Interimrapport 1 : paleolandschappelijk en paleoecologisch onderzoek (parenthese 1), Sint-Niklaas, Archeologische Dienst Waasland.

VAN ROEYEN J.-P., VERBRUGGEN C., KLINCK B. en MEERSSCHAERT L. (2001), “Het Deurganckdok te Doel (Beveren, O.-Vl.). Paleolandschappelijk en archeologisch onderzoek", Annalen van de Koninklijke Oudheidkundige Kring van het Land van Waas, 104, pp. 437-484.

VAN ROEYEN J.-P. (red.) (2003a), Paleolandschappelijk, paleo-ecologisch en archeologisch onderzoek van de op te hogen gronden in het kader van MIDA 1 en MIDA 2 en van de graafwerken voor de kaaimuren van het Containergetijdendok-West (Gemeente Beveren), Interimrapport 3 : natuurwetenschappelijk laboonderzoek (parenthese 3), Sint-Niklaas, Archeologische Dienst Waasland.

VAN ROEYEN J.-P. (red.) (2003b), Archeologisch en paleolandschappelijk onderzoek in het kader van het Verrebroekdokproject (Beveren, O.-Vl.), Eindrapport : synthese van de onderzoeksresultaten, Sint-Niklaas, Archeologische Dienst Waasland.

VAN ROEYEN J.-P. (red.) (2004a), Paleolandschappelijk en archeologisch onderzoek van de te realiseren verkaveling Kieldrecht-Kouter (Gemeente Beveren), Eindrapport, Sint-Niklaas, Archeologische Dienst Waasland.

VAN ROEYEN J.-P. (red) (2004b), Paleolandschappelijk en archeologisch onderzoek van de te realiseren natuurcompensatiezones "Plas Drijdyck" en "Zoetwaterkreek" in het kader van de bouw van het Containergetijdendok-West (Gemeente Beveren), Interimrapport 1 : paleolandschappelijk en archeologische 
screening aan de hand van oppervlakteprospectie en boringen (parenthese 1), Sint-Niklaas, Archeologische Dienst Waasland.

VAN ROEYEN J.-P. (red) (2004c), Paleolandschappelijk en archeologisch onderzoek van de te realiseren natuurcompensatiezone Steenlandpolder te Kallo in het kader van de natuurcompensatieregeling voor de bouw van het Containergetijdendok-West (Gemeente Beveren), Eindrapport : synthese van de onderzoeksresultaten, Sint-Niklaas, Archeologische Dienst Waasland.

VAN ROEYEN J.-P. (red) (2005), Paleolandschappelijk en archeologisch onderzoek van de te realiseren uitbreiding van de ambachtelijke zone Aven Ackers te Verrebroek (Gemeente Beveren), Interimrapport 1 : Paleolandschappelijke en archeologische screening aan de hand van boringen (parenthese 1), Sint-Niklaas, Archeologische Dienst Waasland.

VERBRUGGEN C. (1979), "Vegetational and palaeoecological history of the Lateglacial period in Sandy Flanders (Belgium)”, Acta Univ. Oul. A.82, Geol., 3, pp. 133-142.

VERBRUGGEN C., DENYS L. en KIDEN P. (1996), "Belgium”, Palaeoecological events during the last 15000 years: regional synthesis of palaeoecological studies of lakes and mires in Europe, pp. 554-574.

\section{NOTES}

1. $\mathrm{TAW}=$ Tweede Algemene Waterpassing

\section{RÉSUMÉS}

Sinds de 70-er jaren van de 20ste eeuw wordt de haven van Antwerpen ook op de linkeroever van de Schelde uitgebouwd. De grote infrastructuurwerken die hiermee gepaard gaan, geven de mogelijkheid om in de Wase Scheldepolders alle mogelijke oppervlakken (inclusief het archeologisch vondstenmateriaal) in samenhang met hun verschillende landschappelijke kenmerken in situ te bestuderen.

In het eerste deel wordt er uitvoerig ingegaan op de gehanteerde methodologie, waarbij "Plas Drijdyck" wordt gebruikt als voorbeeld. Aan de hand van de studie van dit gebied wordt de aanpak voor de verschillende occupatiefasen aangetoond.

In een tweede deel wordt de landschapsgeschiedenis van de Wase Scheldepolders besproken, waarbij de nadruk op het laatste deel van het Pleistoceen en het Holoceen ligt. Het geeft een overzicht van de resultaten van het natuurwetenscheppelijk onderzoek dat reeds werd uitgevoerd in deze zone.

The expansion of the Antwerp Harbour since the seventies of previous century demanded great infrastructural changes. Together with these industrial adaptations, scientific insight about the archaeological context and the knowledge about the palaeolandscape increased.

The emphasis of the research now lies on the localization and mapping of archaeological sites and the reconstruction of the Quaternary landscape. This area suits perfectly to these aims, due to its very specific location and stratigraphy. These conditions resulted in an excellent preservation of different occupation levels and its specific landscape features.

The first part of this paper gives a thorough explanation on the current methodology in which 
"Plas Drijdyck" is used as a case-study. By means of this example the differentiated approach of the various levels of occupation are demonstrated.

The evolution and history of the landscape in the late Pleistocene and Holocene forms the bulk of the second part. It wants to give an overview of the results of the natural scientifical research, already carried out in the area of the "Wase Scheldepolders".

INDEX

Keywords : Wase Scheldepolders, landscape genesis, palaeolandscape, archaeology, methodology of preventive research

Trefwoorden Wase Scheldepolders, landschapsgenese, paleolandschap, archeologie, methodologie van het preventieve onderzoek

\section{AUTEURS}

\section{LIESELOTTE MEERSSCHAERT}

Archeologische Dienst Waasland, lmeersschaert@gmail.com

JEAN-PIERRE VAN ROEYEN

Archeologische Dienst Waasland, admin@a-d-w.be

\section{CYRIEL VERBRUGGEN}

Laboratorium voor Paleo-ecologie en Landschapsgenese, Vakgroep Geografie,Cyriel.Verbruggen@Ugent.be 